\title{
Studies in the Cytology of Pteridophyta
}

\author{
I. On the Spermatozoid of \\ Pteris cretica L. var. albo-lineata Hk. ${ }^{1}$
}

By

\section{Akira Yuasa}

Received December 13, 1931.

Contributions describing the details of the morphological and physiological features of haplophases in plants can not be considered sufficient, especially in connection with the phylogenetic relationships of plant groups. In Bryophyta, Charophyta, etc. the spermatozoids are biflagellate and their body is elongated and somewhat spiral. The spermatozoids of most Pteridophyta are similar in general to those of Bryophyta but differ in their possesing a more pronounced spiral body and in having numerous cilia arranged along a considerable part of the body. Between this type of spermatozoid of Pteridophyta and that of the higher gymnosperms and angiosperms which have non-motile sperm-cells, are found the intermediate forms of spermatozoids such as those of the cycads and Ginkgoales. Recently in the detailed studies of the spermatozoids of Charophyta, Bryophyta and Pteridophyta, MüHLdorf (8) and Dracinschi (3) have thrown some light on this line of reseach.

The writer having the advantage of modern technique wished to make a more precise comparative study of the morphology of spermatozoids, and also to study the gametogenesis in Pteridophyta. The present paper is concerned with the morphology of the spermatozoid of Pteris cretica L. var. albo-linecta $\mathrm{Hk}$, and its manner of movement.

\section{Material and Methods}

The spores were collected from cultivated plants in the Koishikawa, Botanical Garden, Tokyo Imperial University. On 14th February 1931 the spores were sown on a block of Cyathea-wood packed with the sphagnum in a large Perri-dish and moistened with city water. The

1) Contributions from the Divisions of Plant-Morphology and of Genetics, Botanical Institute, Faculty of Science, Tokyo Imperial University, No. 1c8. 
spores were also sown on the wet sphagnum in the Petri-dish. This Petri-dish was kept in the green-house in which the temperature was $20-25^{\circ} \mathrm{C}$. At the beginning of March the spores began to germinate and at the end of the month some spores developed the cordate prothallia, but most of the germinated spores remained filamentous. Even the filamentous prothallia bore many antheridia, but no archegonia were formed, which often result in an apogamous growth of sporophytes. The observation was made between June and July 1931.

The spermatozoids were observed either in the fresh state or in the material stained with such dyes as gentian violet, methyl greenacid fuchsin, safranin, orange $G$, and anilin blue. For staining, the aceto-carmine method and the LöFFLER's cilia-staining method were both used.

When the prothallia (mostly filamentous) were mounted on a slide with a drop of the city water (the city water seemed to give better results than distilled water), many spermatozoids were obtained after about five minutes: they were swimming actively here and there. In most cases the spermatozoids were fixed by the osmic fume, but using this method they often shrank and stained homogeneously. So the following somewhat rough method was often used: a hanging water drop containing living spermatozoids was made and after evaporation, the spermatozoids were stained directly with various dyes. Sometimes a drop of aceto-carmine was added to the hanging drop of spermatozoids to fix and stain them. As the staining methods deform the spermatozoids, they were observed also in the living state and compared with those that had been stained.

\section{The Morphology of the Spermatozoids}

An account of the general morphology of a spermatozoid stained with gentian violet is here given (Figs. 1,2).

The spermatozoid is flat-shaped and has 2.5-3.5 coils. The direction of the coils is right-handed, but in a few cases it is left-handed. The anterior part of the spermatozoid is cut-ended, somewhat narrower than the middle, while the posterior tapers off. Between the border-brim ["Randsaum" of Dracinschi (3), "Randleiste" of MüHLdorf (8), "färbbare Faden" of BelajefF (2), the "outer edge of the band" of SHAw (11)] and the nucleus which gradually becomes narrower at the anterior part, the unstained (or lightly stained) region can be seen: this is the cilia-bearing band ["Stamm des Bewegungsapparats" of MüHLdonf (8), "Stamm des Bewegungsorgans" of Dracinschi (3), the 
"almost stainless band" of SHaw(11)]. The ciliabearing band is cytoplasmic, and the border-brim consists of a substance similar to the nuclear substance. These structures were stated particularly in the case of Alsophila sp. and Ceratopteris thalictroides [MüHLDOREF (8)] and Nephrodium thelypteris, Athyrium filix foemina, Osmunda regalis, and Nephrodium austriacum [Dracinschi (3)].

Cilia are grown on one side of about 1.5 coils of the anterior portion of the cilia-bearing band, and their number of 200 spermatozoids varies between 30 and 65 as shown in Table 1 and Fig. 3 where the frequency curve is poly-

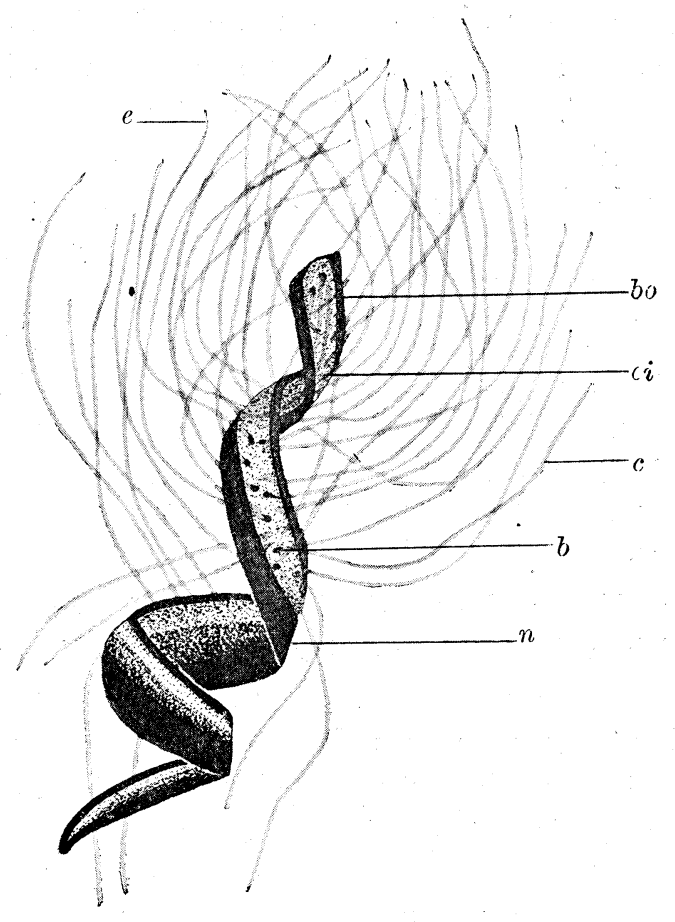

Fig.1- A spermatozoid of Pteris cretica L. var. albo-lineata $\mathrm{Hk}$. stained with gentian violet. The figure was drawn with the aid of the Zerss's drawing apparatus, with a ZeIss HI 90, N.A. 1.25, and comp ocular $\times 20 . \times 2133$.

$b$, basal swollen point of cilium; $c$, cilium; $e$, end-piece; $n$, nucleus; $b o$, border-brim; $c i$, cilia-bearing band. modal, 40 being the highest. The mean is 45.915 .

Table 1

Frequency distribution for number of cilia of 200 spermatozoids in Pieris cretica L. var. albo-lineata Hk.

\begin{tabular}{c|cccccccccccccccccc}
\hline $\begin{array}{c}\text { Nos. } \\
\text { of cilia }\end{array}$ & 30 & 31 & 32 & 33 & 34 & 35 & 36 & 37 & 38 & 39 & 40 & 41 & 42 & 43 & 44 & 45 & 46 & 47 \\
\hline Frequency & 1 & 1 & 2 & 1 & 1 & 5 & 5 & 4 & 4 & 13 & 18 & 15 & 10 & 8 & 8 & 13 & 9 & 7 \\
\hline $\begin{array}{c}\text { Nos. } \\
\text { of cilia }\end{array}$ & 48 & 49 & 50 & 51 & 52 & 53 & 54 & 55 & 56 & 57 & 58 & 59 & 60 & 61 & 62 & 63 & 64 & 65 \\
\hline Frequency & 6 & 9 & 10 & 5 & 7 & 9 & 3 & 8 & 6 & 1 & 2 & 2 & 2 & 2 & 0 & 1 & 1 & 1
\end{tabular}

The border-brim and the nucleus stain deep blue-violet, in almost the same tone, with gentian violet. By using the other dyes these 
two parts also show almost the same colouring. Generally speaking, in ferns the length of the border-brim is equal to that of the cilia-bearing band and ocupies about half the length of a spermatozoid. However, in the example shown in Fig. 1 , the cilia-bearing band runs along the whole length of the body and reaches the posterior end. At the posterior part of the spermatozoid, an unstained (or lightly stained) portion seems to exist.

The cilia-bearing band is unstained or

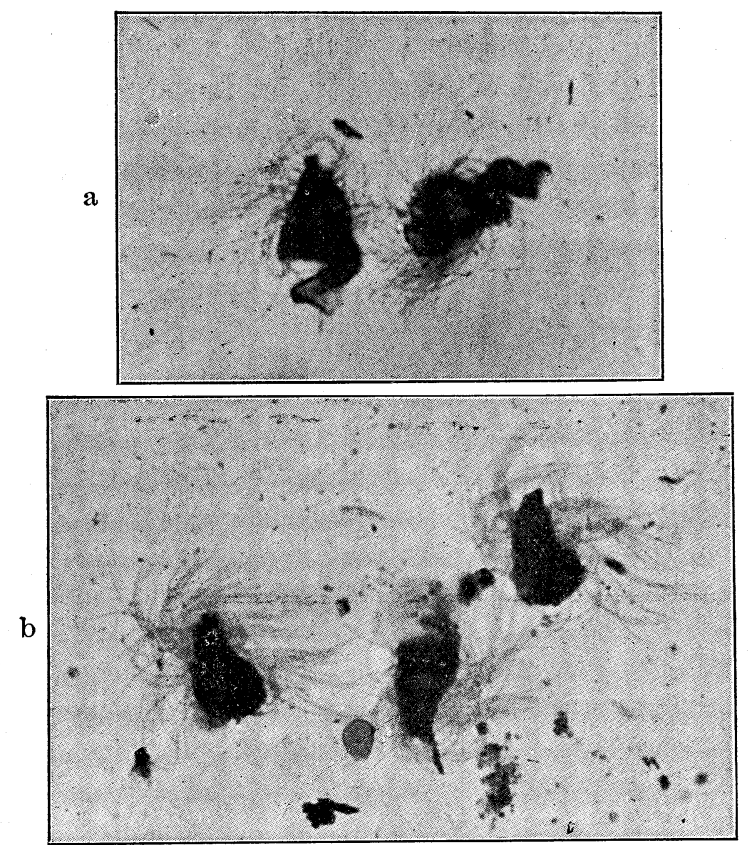

Fig.-2. Microphotographs of the spermatozoids of Pteris cretica L. var. albo-lineata Hk. ca. $\times 700$. $a$, stained with gentian violet; $b$, stained by the LöFFLER's cilia-staining method.

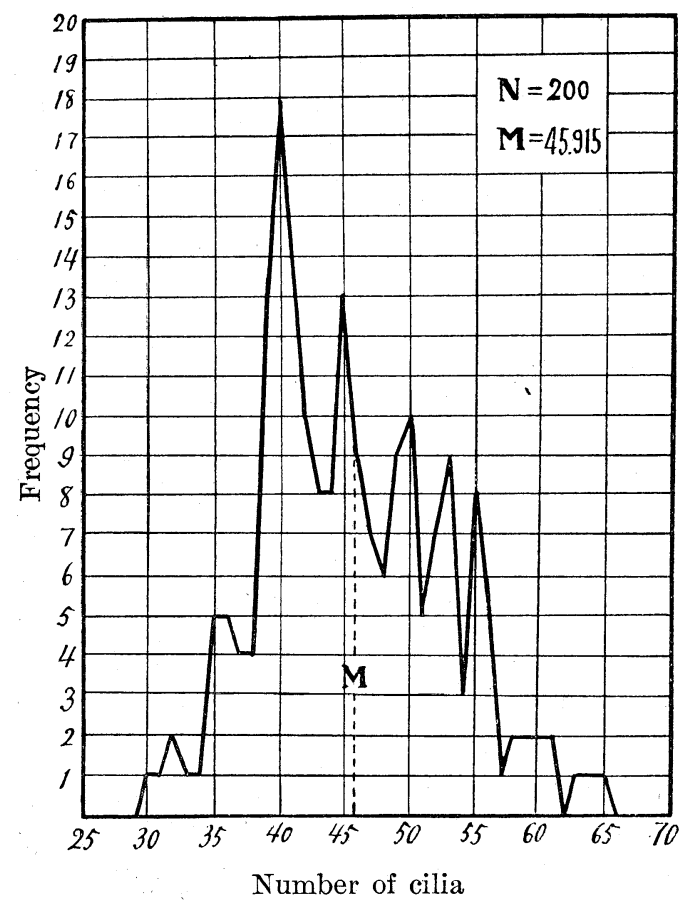

slightly stained with gentian violet, methyl green, haematoxylin, or safranin, but can be stained clearly with cobalt blue, or orange G. With aceto-carmine, the cilia-bearing band is often destroyed. These facts seem to show that the cilia-bearing band is cytoplasmic.

As the border-brim can be distinguished as a distinct body, so the ciliabearing band may be formed between the korder-brim and the nucleus, or may be a part of the cytoplasm in Fig.3- Curve showing variation in number of cilia of 200 spermatszoids of Pteris cretica L. var. albo-lineata Hk. 
which the nucleus is enclosed as suggested by BeLAJEFF (1) on the spermatozoids of ferns and by Liebig (5) on the spermatozoid of Isoëtes. It is probable that the cilia-bearing band is a specially organized region formed between the border-brim and the nucleus, from which grow forth the cilia.

The spiral of the spermatozoid is often seen covered by cytoplasm in which many granules are found; some of these granules may be starch grains which stain violet with iodine solution, while some stain brown. Cilia are stained yellow with the iodine solution.

With methyl green and acid fuchsin, cilia are stained lightly red; the cilia-bearing band purple, and the remainig part green; thus the three parts are clearly distinguishable.

The spermatozoid of this species is relatively large; its length is about $26 \mu$ in the swimming state, but after death it becomes somewhat larger, its length being about $30 \mu$.

In Nephrodium thelypteris, Alsophila sp., and Ceratopteris thalictroides the basal points of cilia were observed by MüHLDoRF (8) and Dracinschi (3) to be arranged regularly, while in Pteris, there was no such regular arrangenent. In living spermatozoids, the bases of cilia are observed to be swollen and such swollen points are stained by aceto-carmine, gentian violet or by the method of the LöFFLER's ciliastaining.

Dracrnschi (3) stated that the cilia of the spermatozoids of Athyrium filix foemina were seen to be fibrous after maceration, but in Pteris such fibrous cilia could not be observed. When the cilia are treated with aceto-carmine, however, they are often seen to be zigzag. The ends of the cilia seem to be round in the living spermatozoid, though they appear to be tapering off when stained by the method of the cilia-staining, and show the so-called end-pieces. The cilia are often one-half times as long as the length of the body of the spermatozoid, but sometimes the former are shorter than the latter.

Fixed and staind with aceto-carmine, the nucleus and the borderbrim become a distinct red and the cilia are often seen stained lightly red. When treated with high-concentrated aceto-carmine or the boiling method, the cilia and the cilia-bearing band can not be seen at all. At the moment of adding a drop of acetic acid to a hanging drop containg the spermatozoids they die uncoiled, while in the glycerine solution they die in a tightly coiled state.

Stained with aceto-carmine, many dark-red granules are seen ranging on the margin of the nucleus, on the inner part of which many lightly dark-red granules are also to be observed mingling with the 
light-reflecting granules which are found also in the cytoplasm. The above-mentioned dark-red granules are seen in Leptogramme totta and Adiantum capillus-veneris, when extremely differentiated in iron-alum after staining with haematoxylin. These granules seem to be chromomeres. Dracinschi (3) stated that "Trockenausstriche", fixed first with CARNoy's fluid and then treated with aceto-carmine after HerTz's boiling-method, showed the nuclear structure of the spermatozoid fairly clearly: that is, dark chromomeres are seen in the clearly stained nuclear lymph. This structure was probably described by ScHоттLÄNDER (10) as "spiralige Hülle" of the spermatozoid of Gymnogramme chrysophylla, Aneura pinguis, Marchantia polymorpha, and Chara foetida, but this must be left for further investigation.

\section{The Movement of the Spermatozoids}

N̈̈GELI (9) described as early as 1844 the movement of the spermatozoids of ferns. In 1905 Mryake (7) published a paper dealing with the same subject in Cycas revoluta. The detailed studies of the mechanism of the movement of the spermatozoids were made in 1923 by Metzner (6) in Chara foetida, Pressia communata, Marchantia polymorpha and various ferns, especially Blechnum spicant and Adiantum cuneatum. In 1926 Showalter (10) also studied the movement of the spermatozoids" of Riccardia pinguis. The chemotaxis of pteridophytic spermatozoids was studied in detail by Shibata $(12,13)$ in 1911. The results obtained by the writer are here stated.

When the prothallia are mounted on a slide with a drop of water, many spermatozoids are seen swimming actively after 5-10 minutes. At first, the wall-cells of an antheridium swell by absorbing water (Fig. 4 , a); then the spermatogenous mass swells and presses against the wall-cells for a time, resulting in a little diminution of the volume of the wall-cells (Fig. 4, b). In this process, the spermatogenous mass is pushed up to the opercular-cell, so that the wall-cells once more swell and push up again the spermatogenous mass against the opercular-cell (Fig. 4, c). At last the opercular-cell is broken and spermatids are thrown out (Fig. 4, d, side view; e, top view ). The wall-cells of an antheridium contain several small chlorophyll-grains. According to WADA (15) the antheridium of Isoëtes has the "swell substance" which make the spermatozoids extrude. Hartmann (4) said that the opening of an antheridium is caused by the swelling of the spermatogenous mass.

The number of spermatids which are contained in an antheridium 


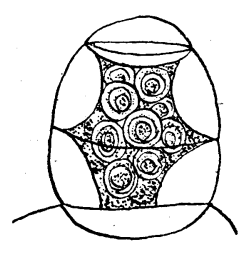

a

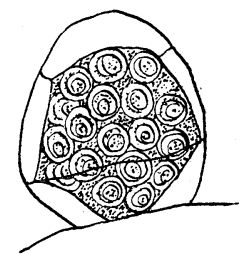

$\mathrm{b}$

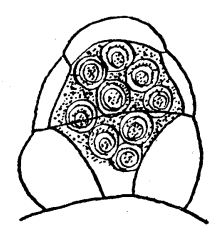

c

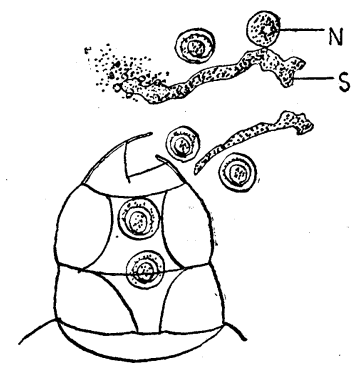

d

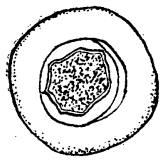

e

Fig. 4. The dehiscence of the antheridium. N, nucleus of the opercularcell; S, Slime of the spermatogenous mass and contents of the opercularcell.

is not constant; in some antheridia eight spermatids are formed, while in others sixteen or sixty-four.

The spermatids which contain the mature spermatozoids are extruded out of an antheridium. In some cases the spermatozoids break the spermatids and move away at once, but in other cases they first rotate slowly in the spermatids and then, stretching their anterior ends out of the spermatids, they gradually increase their rate of rotation, by means of their cilia; finally they push away the spermatidmembranes which still contain cytoplasm towards the posterior ends, and begin to swim. In these spermatids which are pushed away towards the posterior ends of the spermatozoids, granules are often oscillating with the Browvian movement. At this time, cytoplasm remains in and around the spiral of the spermatozoid. Sometimes the spermatid-membrane and some of the cytoplasm are thrown off and the remaining cytoplasm in the spiral is pushed out and adheres at the posterior end of the spermatozoid as a globular body. The spermatozoid which can not stretch out of the spermatid-membrane completely, dies in a short time.

The cilia, by waving around the body of the spermatozoid while swimming, make it rotate, but they twist around the body when the spermatozoid dies. According to SHowalter (14) the spermatozoid of Riccardia pinguis revolved both round a definite point and on its axis, but in the writer's material this regular revolution round definite 
points can not be seen. When the spermatozoids are freed from the antheridium, they begin to swim in different directions. The spermatozoid rotates in a direction opposite to that of the spiral: the rotation of the spiral is caused by the cilia. The direction of movement is not only forwards, but also transversally. Sometimes the spermatozoids can retreat. The velocity of the forward movement is $0.75-1$ $\mathrm{mm} / \mathrm{sec}$. in active state.

The duration of the life of the fern-spermatozoids is, in general, about one hour, but in Pteris cretica L. var. albo-lineata Hk. about thirty minutes. The shortness of the life of this fern-spermatozoids may be correlated with its apogamous condition which makes the spermatozoids rather unnecessary for reproduction.

Résumé

1. The body of the spermatozoid of Pteris cretica L. var. albolineata Hk. is spiral-shaped of 2.5-3.5 coils. The direction of the spiral is right-handed with some exceptions. Both the cilia-bearing band and the border-brim can be traced along the whole length of the spermatozoid. The cilia grow forth from one side of about 1.5 coils of the anterior part of the cilia-bearing band.

2. The number of cilia of 200 spermatozoids shows a variation ranging from 30 to 65 , the mean being 45.915. The end of the cilia are seen to be tapering off which is shown by certain stainning methods.

3. The border-brim is apparently a specially organized region which is shown by both its staining-reaction and its appearance during the spermatogenesis as well as after completion of the spermatozoid.

4. Treated with the aceto-carmine, karyolymph and chromomeres can be distinguished.

5. The dehiscence of an antheridium is caused by the combined action of the swelling of the wall-cells and that of the spermatogenous mass.

6. In most cases as soon as the spermatozoids become free from the antheridium, they begin to swim freely. For a time the swimming spermatozoids have the residue of spermatids on their posterior end. Their movement is due to the action of the cilia. The direction of the rotating of the spermatozoid is contrary to that of the body-spiral. The velocity of the movement is $0.75-1 \mathrm{~mm} / \mathrm{sec}$. in active state. 
The writer's thanks are due to Dr. Siñotô for helpful criticism and suggestions during the course of the work.

October 1931

Botanical Institute, Faculty of Science, Tokyo Imperial University

\section{Literature}

1. Belajeff, W. 1889. Ueber Bau und Entwicklung der Spérmatozoiden bei den Gefässkryptogamen. Ber. d. Deut. bot. Gesells. 7 : 122-125.

2. 1898. Ueber die Cilienbildner in den spermatogenen Zellen. Ber. d. Deut. bot. Gesells. 16 : 140-144.

3. Dracinschr, M. 1930. Über das reife Spermien der Filicales und von Pilutaria globulifera L. Ber. d. Deut. bot. Gesells. 48 : 295-311.

4. Hartmann, M. E. 1931. Antheridial dehiscence in the Polypodiaceae. Bot. Gaz 91 : $252-276$.

5. Liebig, J. 1931. Ergänzungen und Entwicklungsgeschichte von Isoëtes lacustre L. Flora 25 : 321-358.

6. Metzner, P. 1923. Studien über die Bewegungsmechanik der Spermatozoiden. Zeitschr. f. wiss. Bot. 1 : 168-188.

7. Mryake, K. 1905. On the spermatozoid of Cycas revoluta. (Japanese). Bot. Mag. (Tokyo) $19: 234-240$

8. MüHLDorf, A. 1930. Berichtungen und Ergänzungen unserer Kentnisse über die Morphologie und Histologie pflanzlicher Spermien. Biol. Gen. 6 : 457-482.

9. N̈̈GELI, C. 1844. Bewegliche Spiralfäden an Farnen. Zeitschr. f. wiss. Bot, 1 : 168-185.

10. Schotrländer, P. 1893, Beträge zur Kentniss des Zellkerns und des Sexualzellen bei Kryptogamen. Cohn's Beitr. d. Pflanz. 6 : 267-304.

11. Shaw, W. R. 1898. The fertilization of Onoclea. Ann. of Bot. 12: 261-285.

12. Shibata, K. 1905. Studien über die Chemotaxis der Isoëtes-spermatozoiden. Ber. d. Deut. bot. Gesells. 41 : 561-610.

13. 1911. Untersuchungen über die Chemotaxis der Pteridophyten-Spermatozoiden. Jahrb. f. wiss. Bot. 49: 1-60.

14. Showalter, A. M. 1926. Studies in the cytology of Anacrogynae. I. Antherozoid. Ann. of Bot. $40: 691-707$.

15. WADA, B. 1930. Mikrurgische Untersuchungen über die Entlassung der Spermatozoiden von Isoëtes. Cytologia 1 : 285-307. 